\title{
AMD1 wt Allele
}

National Cancer Institute

\section{Source}

National Cancer Institute. AMD1 wt Allele. NCI Thesaurus. Code C102774.

Human AMD1 wild-type allele is located in the vicinity of $6 q 21$ and is approximately $21 \mathrm{~kb}$ in length. This allele, which encodes S-adenosylmethionine decarboxylase proenzyme protein, plays a role in the synthesis of both spermine and spermidine. 